2011s-60

\title{
Sustainable Tourism Indicators: Selection Criteria for Policy Implementation and Scientific Recognition
}

\author{
Georges A. Tanguay, Juste Rajaonson, Marie-Christine Therrien
}

\begin{tabular}{c}
\hline Série Scientifique \\
Scientific Series
\end{tabular}

\section{Montréal}

Septembre 2011

(C) 2011 Georges A. Tanguay, Juste Rajaonson, Marie-Christine Therrien. Tous droits réservés. All rights reserved. Reproduction partielle permise avec citation du document source, incluant la notice (C). Short sections may be quoted without explicit permission, if full credit, including (C) notice, is given to the source.
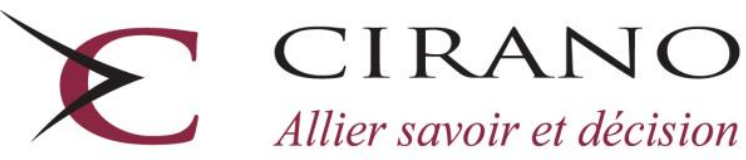

Allier savoir et décision

Centre interuniversitaire de recherche en analyse des organisations 


\section{CIRANO}

Le CIRANO est un organisme sans but lucratif constitué en vertu de la Loi des compagnies du Québec. Le financement de son infrastructure et de ses activités de recherche provient des cotisations de ses organisations-membres, d'une subvention d'infrastructure du Ministère du Développement économique et régional et de la Recherche, de même que des subventions et mandats obtenus par ses équipes de recherche.

CIRANO is a private non-profit organization incorporated under the Québec Companies Act. Its infrastructure and research activities are funded through fees paid by member organizations, an infrastructure grant from the Ministère du Développement économique et régional et de la Recherche, and grants and research mandates obtained by its research teams.

\section{Les partenaires du CIRANO}

\section{Partenaire majeur}

Ministère du Développement économique, de l'Innovation et de 1'Exportation

\section{Partenaires corporatifs}

Autorité des marchés financiers

Banque de développement du Canada

Banque du Canada

Banque Laurentienne du Canada

Banque Nationale du Canada

Banque Royale du Canada

Banque Scotia

Bell Canada

BMO Groupe financier

Caisse de dépôt et placement du Québec

CSST

Fédération des caisses Desjardins du Québec

Financière Sun Life, Québec

Gaz Métro

Hydro-Québec

Industrie Canada

Investissements PSP

Ministère des Finances du Québec

Power Corporation du Canada

Rio Tinto Alcan

State Street Global Advisors

Transat A.T.

Ville de Montréal

\section{Partenaires universitaires}

École Polytechnique de Montréal

HEC Montréal

McGill University

Université Concordia

Université de Montréal

Université de Sherbrooke

Université du Québec

Université du Québec à Montréal

Université Laval

Le CIRANO collabore avec de nombreux centres et chaires de recherche universitaires dont on peut consulter la liste sur son site web.

Les cahiers de la série scientifique (CS) visent à rendre accessibles des résultats de recherche effectuée au CIRANO afin de susciter échanges et commentaires. Ces cahiers sont écrits dans le style des publications scientifiques. Les idées et les opinions émises sont sous l'unique responsabilité des auteurs et ne représentent pas nécessairement les positions du CIRANO ou de ses partenaires.

This paper presents research carried out at CIRANO and aims at encouraging discussion and comment. The observations and viewpoints expressed are the sole responsibility of the authors. They do not necessarily represent positions of CIRANO or its partners. 


\title{
Sustainable Tourism Indicators: Selection Criteria for Policy Implementation and Scientific Recognition
}

\author{
Georges A. Tanguay ${ }^{*}$, Juste Rajaonson ${ }^{\dagger}$, Marie-Christine Therrien ${ }^{*}$
}

\begin{abstract}
Résumé / Abstract
L'utilisation d'indicateurs de tourisme durable (STI) pose de nombreux problèmes qui résultent principalement des multiples interprétations du développement durable et, de ce fait, du tourisme durable. S'y ajoute l'absence d'un cadre de référence établi résultant de l'incompatibilité entre les attentes et objectifs du milieu académique et du milieu politique et remettant souvent en cause la crédibilité et le bien-fondé des indicateurs. Pour y remédier, nous proposons une liste parcimonieuse d'indicateurs de tourisme durable (STI) basée sur l'application d'une série de critères de sélection. L'ensemble de ces critères permet de choisir, parmi les indicateurs reconnus par les experts, ceux qui couvrent largement les dimensions et les enjeux de développement durable dans le domaine du tourisme, qui sont légitimés par les expériences existantes et qui sont en même temps suffisamment flexibles pour être effectifs et utiles à différentes destinations. Nous croyons que le concours de ces conditions contribuera à la reconnaissance et à la légitimité scientifique et politique des indicateurs. Quatre critères de sélection généraux sont appliqués à une base de données de 507 STI pour en réduire le nombre à un effectif optimal de 20 STI. Ensuite, trois critères spécifiques permettent d'ajuster les 20 STI pour les rendre opérationnels. Nous illustrons cette démarche en appliquant ces critères à la région de la Gaspésie-Îles-de-la-Madeleine, Québec.
\end{abstract}

Mots clés : Indicateurs, tourisme durable, développement durable.

Using sustainable tourism indicators (STI) creates many difficulties resulting mainly from the multiple interpretations of the concept of sustainable development, and by extension of the concept of sustainable tourism. To these difficulties are added an absence of a strong academic background, which is the result of incompatibilities between the needs and objectives of the academic versus the political world, which often challenges the need for indicators. We propose a parsimonious list of sustainable tourism indicators based on the application of a series of selection criteria. From the expert recognized indicators, all of these criteria help us choose the indicators, which cover the dimensions and issues of sustainable development for tourism. They are legitimized by existing experiences and sufficiently flexible to be useful for different destinations. In the end, the intersection of these conditions contributes to the scientific and political recognition of the indicators. We start by applying four general selection criteria to a 507 STI database. This allows us to reduce the list to 20 recognized STI. We end the selection process by applying three specific criteria in order to adjust the 20 STI to render them operational. We illustrate the selection procedure with an example of criteria application to the Gaspésie-Iles-de-la Madeleine region in Quebec.

Keywords: Indicators, Sustainable Tourism, Sustainable Development.

\footnotetext{
* CIRANO and Université du Québec à Montréal (UQAM), ESG-DEUT, C.P 8888, Succ. Centre-ville, Montreal (Quebec), Canada, H3C 3P8. Fax: 514-987-7827; tanguay.georges@uqam.ca.

† Université du Québec à Montréal.

$¥$ École nationale d'administration publique.
} 


\section{Introduction}

The tourism industry is a crucial engine of the global economy. In the last quarter of 2010 , it represented $5 \%$ of international economic activity (World Tourism Organization [WTO], 2010). In 2011, there were 880 million arrivals of international tourists and this number should increase to 1.5 billion tourists in 2020 (WTO, 2011). This substantial economic weight is also reflected in increasing investments by cities, regions and countries to make their main products more attractive. This is easily understandable, given that the tourism industry generates important direct and indirect economic benefits (Sirakaya, Jamal and Choi, 2001). These benefits are translated into many jobs and constitute major sources of income for destination residents. In addition, tourists can contribute to improving the socioeconomic dimension by generating a larger volume of cultural and artistic activities, which in turn lead to greater dissemination of local culture.

Despite their positive impact, tourism activities may have negative effects (Hall and Lew, 1998; Hunter, 1997). For example, in environmental terms, visitors generate solid waste or greenhouse gas through their travels. From a social standpoint, tourism activities can also cause several problems: decreased quality of life due to visitor volume, loss of identity due to outside influences, noise, pollution, etc. Given these positive and negative impacts, sustainable tourism must follow a development path that maximizes the economic benefits while minimizing the impact on the physical and human environment. These objectives must be supported by evaluation tools such as indicators (Miller, 2001; Manning and Dougherty, 1995).

In this article, we propose a parsimonious list of sustainable tourism indicators (STI) based on the application of a series of selection criteria. These criteria help to choose from expert recognized indicators, those legitimized by existing experiences and those sufficiently flexible to be used for different tourism destinations. We estimate that these conditions should contribute to the scientific and political recognition of indicators.

The article is divided in six sections. In Section 2, we present the context and clarify the links between sustainable development concepts and sustainable tourism. In Section 3 we discuss the use of indicators in sustainable tourism by demonstrating their many advantages. Section 4 describes the STI and the case studies retained for the analysis. Section 5 explains the steps and selection criteria of indicators and discusses the pertinence and coherence of the selected STI. The accessibility of the data is also examined. Section 6 addresses the results of the application of both general and specific selection criteria to the STI list. The article concludes with a synthesis of the main results. It also presents a review of the main principles which must guide a sustainable development process for tourism. 


\section{From sustainable development to sustainable tourism}

Historically, the concept of sustainable development has been the subject of many interpretations and definitions. This often has constituted a major problem when it comes to policy making (Bell and Morse, 2008). Given that sustainable tourism is based on the main principles of the concept of sustainable development, it is not surprising that it is subject to many interpretations. To avoid using a "made-to-measure" definition of sustainable tourism, in the current section we relate the traditional principles and dimensions of sustainable development to tourism.

\subsection{Definition and principles of sustainable development}

Sustainable development acquired widespread recognition after the World Commission on Environment and Development published the Brundtland report in 1987. This report recognizes and defines sustainable development as "development that meets the needs of the present without compromising the ability of future generations to meet their own needs" (WCED, 1987). Further, the report underlines two associated key concepts: the concept of "needs", in particular the essential needs of the world's poor, to which overriding priority should be given; and the idea of "limitations" imposed by the state of technology and social organization on the environment's ability to meet present and future needs (WCED, 1987).

Sustainable development is therefore portrayed as an approach that aims for intra- and intergenerational equity, but also as an alternative paradigm to the apparently incompatible arguments put forth by advocates of economic growth and supporters of environmental protection. It is thus a median path of development that attempts to reconcile these two contradictions by recognizing the legitimacy of each side.

\subsection{Definition and principles of sustainable tourism}

The application of these principles to the tourism domain amounts to guaranteeing the long-term sustainability of tourism by reaching equilibrium between the environmental, social and economic aspects of development.

Sustainable tourism implies to make optimal use of environmental resources that constitute a key element in tourism development, maintaining essential ecological processes and helping to conserve natural heritage and biodiversity. Also, it means respecting the socio-cultural authenticity of host communities, conserve their built and living cultural heritage and traditional values, and contribute to inter-cultural understanding and tolerance. Finally, it has to ensure viable, long-term economic operations, providing socio-economic benefits to all stakeholders that are fairly 
distributed, including stable employment and income-earning opportunities and social services to host communities, and contributing to poverty alleviation (WTO, 2004).

Graphic representation using a Venn diagram (Figure 1) is the most widespread and simplest way to illustrate the interaction of the main components of sustainable development (Connelly, 2007). This interaction is formed by the overlapping of three circles representing economic, social and environmental concerns respectively (Beauregard, 2003). This translation of the concept into three dimensions has the advantage of being easy-to-understand by a wide range of actors and potential users. It is more compatible with different domains, notably tourism, and is easily applicable to different scales.

As part of the implementation of sustainable development principles in tourism, this interpretation becomes an organizational framework that can serve as the basis for an indicator grid. The most significant indicators are those that can cover more than one dimension at a time.

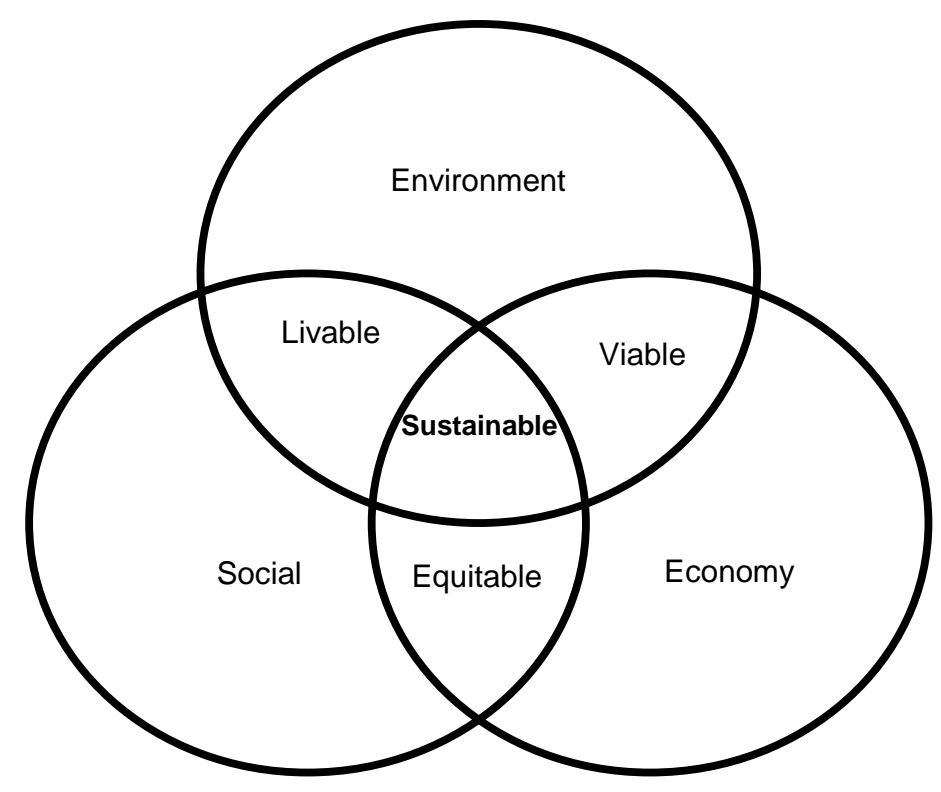

Figure 1 Conceptualization of sustainable development

\section{Sustainable tourism and the use of indicators}

Indicators are part of the main recognized evaluation tools used to support sustainable tourism policy implementation (Choi and Sirakaya, 2006; Miller, 2001). They constitute a set of information that can serve to evaluate important changes in the course of tourism development and tourism management. 
For politicians, indicators correspond to a diagnosis of internal and external factors that affect the structure of the tourism industry. They can also reflect the benefits and impact of tourism on their territory and help to identify priority actions (WTO, 2004). Diagnoses can thus rest on quantitative and qualitative information. For tourism operators, the process of defining indicators is an effective means of attracting attention to key questions and procuring information on the status and conditions of types of capital (i.e. natural and human). Thus, indicators act as a catalyst to support a planning process (Mascarenhas et al., 2010). Lastly, when clear objectives are already in place, indicators can also play a more concrete role in the monitoring and measuring the attainment of objectives. They can determine whether a plan or strategy meets the objectives initially stated. In addition, the fact of considering an indicator tends to favour precision, and in some cases illustrates inconsistencies in the objectives initially set (Bell and Morse, 2008). Consequently, indicators should be updated periodically.

STI are generally used in two distinct contexts: i) comparison between destinations using a series of common indicators and ii) the scorecard or the use of a series of indicators specific to a destination according to specific objectives.

In the case of the common STI grid, selected destinations are compared based on their performance in sustainable tourism. Through this comparison, they gradually develop a more critical attitude toward their own initiatives. They would thus be more likely to maintain a certain performance level and tend to avoid a passive attitude and being satisfied with doing the "strict minimum." In other words, competition would encourage destinations to surpass themselves. This principle is well documented by the European Environmental Agency (2001). However, this approach is very constraining, notably regarding the availability of indicators for the selected destinations and the comparability of theses destinations. However, such a grid can be envisioned for a region or a territory composed with municipalities of similar sizes and characteristics (Tanguay et al., 2009; Rajaonson and Tanguay, 2009).

The scorecard comprises a series of indicators specific to the destination that allow identification of prior sustainable tourism issues. This approach is preferred by public managers because it can be adjusted according to the sustainable development concerns and characteristics specific to each destination (Bell and Morse, 2008). Further, regions tend to develop their own indicators according to their particular needs (Bouni, 1998). By adopting this approach, one can measure the evolution of tourism over time and adjust its policy and its tourism action plan when necessary. Further, the indicators must be reevaluated periodically.

Even if a destination would benefit from adopting its own indicators grid, it is recommended that it begin by ensuring the neutrality and pertinence of indicators 
(Tanguay et al. 2009). The STI selected can then be adjusted, validated and adopted by regional decision-makers.

\section{Inventory of existing STI and description of studies retained}

Before selecting key indicators of sustainable tourism, we have compiled a database of indicators based on the World Tourism Organization's Indicators of Sustainable

Development for Tourism Destinations: A Guidebook (WTO, 2004).

In chapter 3 of the guidebook, the indicators are distributed within 42 issues, presented in 13 sections. Each section covers a particular theme by discussing trends and problems and making recommendations regarding the indicators proposed (WTO, 2004). Initially, 768 indicators were compiled, but several of them were removed because of redundancy. For example, the numbers of tourists per day, per week and per month were used to examine different issues, notably the impact of tourism on the life of the local community, encroachment on vulnerable sites and seasonality of the use of sites (WTO, 2004 , p. 58, 112, 193). Our main database derived from the WTO guidebook contains 507 indicators.

In addition, we consulted 16 case studies that deal with sustainable tourism indicators applied to different geographical zones: cities, regions, and countries. 13 case studies were presented in the WTO guidebook. In five of them, the list of indicators is partial. Therefore, we decided not to keep these five case studies and opted finally for 11 case studies (Table 1).

Table 1 Summary of the 11 case studies examined

\begin{tabular}{|c|c|c|}
\hline Destination & $\begin{array}{l}\text { Number of } \\
\text { indicators }\end{array}$ & Comments \\
\hline $\begin{array}{r}\text { International } \\
(\mathrm{WTO}, 2004)\end{array}$ & $\begin{array}{l}768 \text { indicators, } \\
29 \text { of which are } \\
\text { basic }\end{array}$ & $\begin{array}{l}29 \text { basic indicators ranked by main issues in } \\
\text { sustainable tourism and applicable to all types of } \\
\text { destinations }\end{array}$ \\
\hline $\begin{array}{r}\text { International } \\
(\text { Vellas, 2000) }\end{array}$ & 10 indicators & $\begin{array}{l}10 \text { indicators compatible with all types of destinations, } \\
\text { divided into several measures to encompass } \\
\text { quantitative and qualitative aspects }\end{array}$ \\
\hline $\begin{array}{r}\text { European cities (European } \\
\text { Environmental Agency, 2004) }\end{array}$ & 11 indicators & $\begin{array}{l}11 \text { key indicators compatibles with destinations in } \\
\text { European countries and the West in general }\end{array}$ \\
\hline $\begin{array}{l}\text { Albufera de Valencia } \\
\qquad(\text { WTO, 2004) }\end{array}$ & 141 indicators & $\begin{array}{l}141 \text { indicators of pressure, state and response to } \\
\text { measure the capacity of an ecosystem of attractive but } \\
\text { vulnerable natural landscapes }\end{array}$ \\
\hline $\begin{array}{r}\text { Balearic Island } \\
(\mathrm{WTO}, 2004)\end{array}$ & 50 indicators & $\begin{array}{l}50 \text { indicators for a destination where tourism is the } \\
\text { main sector }\end{array}$ \\
\hline $\begin{array}{l}\text { Canary Island } \\
(\mathrm{WTO}, 2004)\end{array}$ & 9 indicators & $\begin{array}{l}9 \text { Indicators that serve as a guide in the sustainable } \\
\text { tourism planning process for a coastal destination }\end{array}$ \\
\hline $\begin{array}{r}\text { Cape Breton Island, Canada } \\
\text { (WTO, 2004) }\end{array}$ & 30 indicators & $\begin{array}{l}30 \text { indicators resulting from a participating approach } \\
\text { compatible with all types of destinations }\end{array}$ \\
\hline
\end{tabular}




\begin{tabular}{rcl}
\hline $\begin{array}{r}\text { aribbean Region } \\
\text { (WTO, 2004) }\end{array}$ & $\begin{array}{c}14 \text { normative } \\
\text { indicators }\end{array}$ & $\begin{array}{l}\text { 14 normative indicators that demonstrate the progress } \\
\text { toward a common set of indicators for regions where } \\
\text { tourism is an important engine of the economy }\end{array}$ \\
\hline $\begin{array}{r}\text { Kukijuca, Croatia } \\
\text { (WTO, 2004) }\end{array}$ & 44 indicators & $\begin{array}{l}44 \text { indicators resulting from a WTO workshop on } \\
\text { indicators in 2001, applicable to all types of } \\
\text { destinations }\end{array}$ \\
\hline $\begin{array}{r}\text { Samoan islands } \\
\text { (WTO, 2004) }\end{array}$ & 20 indicators & $\begin{array}{l}20 \text { indicators adopted by the Project Advisor } \\
\text { Committee made up of elected officials }\end{array}$ \\
$\begin{array}{r}\text { Switzerland } \\
\text { (JSS, 2007) }\end{array}$ & 20 indicators & $\begin{array}{l}20 \text { indicators defined in the DPSIR (Drivers, Pressure, } \\
\text { State, Impact, Response) system applicable to all types } \\
\text { of destinations. }\end{array}$ \\
\hline
\end{tabular}

\section{Methodology}

To obtain a list of pertinent and operational STI, we apply, in turn, seven selection criteria to the initial 507 indicators retained. We differentiate selection criteria that are general (4) and specific (3) to a destination (Figure 2). The general selection criteria are the basis which allows us to reduce the expert recognized exhaustive list into a parsimonious STI list, applicable to all destinations. The specific selection criteria help to adjust the indicators so they can be integrated in the tourism evaluation process through a sustainable development perspective.

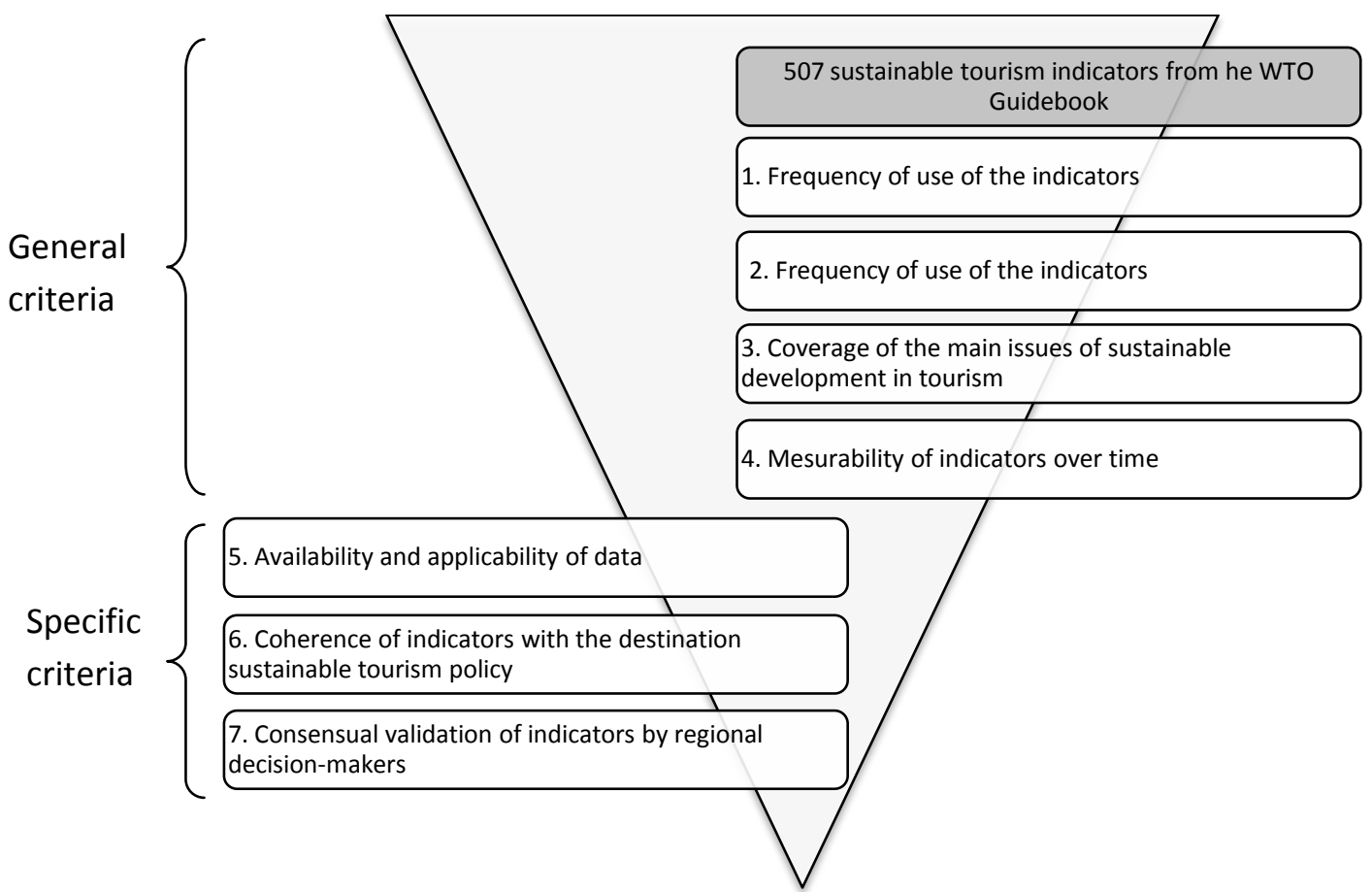

Figure 2 Selection criteria of sustainable tourism indicators 
The general criteria are the classification of the 507 indicators, the frequency of use of STI in the 11 studies sampled, coverage of the WTO's main issues of sustainable development in tourism and the measurability of indicators over time. These four criteria are intended to reduce the initial 507 indicators to a more concise list, which covers the sustainable development dimensions and issues as well as the initial list does.

The three other criteria aim to obtain applicable indicators for a specific destination by ensuring that the data are available, that the indicators are consistent with the regional policy and that decision-makers validate and adopt the indicators consensually.

Seven corresponding steps are necessary to reduce the 507 indicators to a more concise and operational list. First, we classify the 507 initial indicators according to the classic components of sustainable development. The objective of this step is to identify and distinguish indicators related to the environmental, social and economic components and those found at their intersections. For tourism in a given territory to be able to follow a sustainable development path, it must be equitable (interaction between the economy and society), livable (ability of the environment to meet social needs, which can refer to the concept of quality of life), and viable (economic development must take place with respect for the supportive capacity of ecosystems while avoiding the depletion of nonrenewable resources).

Second, we identified the most frequently used STI from among the initial list of 507 indicators, in the 11 studies selected. We thus obtain a reduced list of STI whose use and pertinence have often been demonstrated. Further, these indicators have achieved consensus among experts and their value is recognized.

Third, we define a threshold from which the reduced list of STI allows us to reproduce the coverage of dimensions of sustainable development of the initial 507 indicators as broadly as possible. By ensuring this correspondence, we aim to make this reduced list of indicators as representative of the coverage of the components of sustainable development as the initial 507 indicators. We also confirm that this reduced list of STI also covers the main issues of sustainable development as defined in the WTO guidebook on sustainable tourism indicators. These issues can be regrouped in 20 categories (Table 2). 
Table 2 Issues of sustainable development in tourism

\begin{tabular}{rlrl}
\multicolumn{1}{c}{$\mathbf{N}^{\circ}$} & Issues & $\mathbf{N}^{\circ}$ & Issues \\
\hline 1 & Ecosystem & 11 & Public participation \\
\hline 2 & Water & 12 & Culture \\
\hline 3 & Atmosphere & 13 & Accessibility \\
\hline 4 & Energy & 14 & Investments \\
\hline 5 & Waste & 15 & Promotion of ecotourism \\
\hline 6 & Landscapes and nuisances & 16 & Economic vitality \\
\hline 7 & Resilience and risk & 17 & Employment \\
\hline 8 & Security and safety & 18 & Marketing \\
\hline 9 & Health & 19 & Distinction \\
\hline 10 & Satisfaction & 20 & Traffic \\
\hline
\end{tabular}

At this step, when an issue is overrepresented (i.e. two or more indicators describe the same issue), at least one indicator corresponding to the issue is removed. When an issue is underrepresented, an indicator corresponding to the issue is added. The choice of indicators to add or remove in case of overrepresentation or underrepresentation is based on the criterion of frequency of use in the 11 case studies. This helps to choose indicators for which their purpose is already recognized, demonstrated and legitimized by successful experiences.

Nonetheless, when two indicators have the same usage frequency, we used the rating system developed by Choi and Sirakaya (2006). These scores are based on a Delphi study and correspond to the aggregation of the rate obtained by 125 indicators on a scale of 1 to 5 , by a panel of 36 tourism experts. Therefore, when two indicators have the same usage frequency, we select the one with the highest score according to the Choi and Sirakaya rating.

Forth, we ensure that the data are measurable over time because the STI will serve to measure evolution. Static indicators are therefore removed and replaced by dynamic indicators.

Fifth, we use the case of the Gaspésie-Îles-de-la-Madeleine region in Quebec to illustrate the application of specific criteria of the STI, which result from the precedent steps. In 2011, this region started a process of STI selection in order to develop and also evaluate a Sustainable Tourism Policy adopted in 2010 by the regional conference of elected representatives (Conférence regionale des élus de la Gaspésie-Îles-de-la-Madeleine [CRÉGÎM], 2010). The selection process of indicators is at its preliminary stage and the criteria application proposed in this article is considered by the administrative officers of the CRÉGÎM. An indicator for which data are not available for the destination may be 
replaced by an alternative and equivalent indicator (for which data are available). This is crucial if the indicators are to be effective. At this step, it is evident that subjectivity is necessarily introduced. However, the chosen indicators must be able to cover the same issues as the indicators they are replacing.

Sixth, we verify and analyse the coherence of the resulting STI set with the tourism policy framework of the destination. To do so, each indicator is classified, this time according to the guiding principles of the destination's policy framework.

The seventh and last step consists is a consensual validation of the proposed list of STI regional decision-makers.

\section{Results}

\section{Step 1: Classification of the 507 initial indicators}

The classification of the initial list of indicators demonstrates the diversity of STI, along with the importance placed on the social and economic dimensions in actual experience regarding indicators. Social and economic indicators, along with those found at the intersection of these two dimensions, collectively represent $56.4 \%$ of the 507 indicators.

This classification also demonstrates that most of the STI affect at least two of the three dimensions of sustainable development simultaneously. $60.8 \%$ of the indicators are situated in the overlapping areas (Figure 3). These percentages should be found in the reduced list of key indicators we recommend.

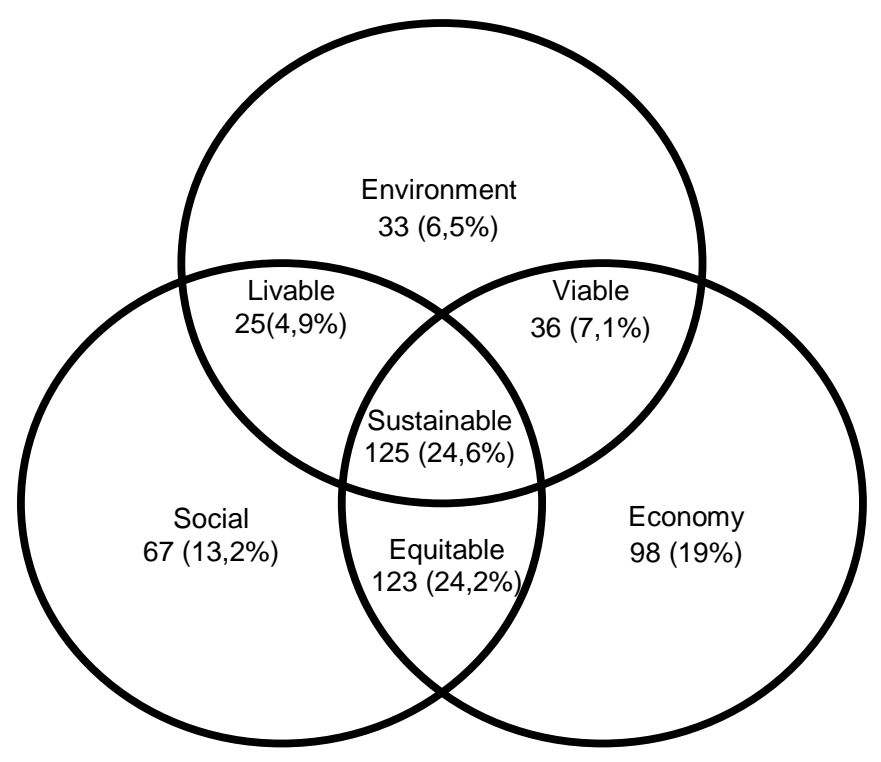

Figure 3 Classification of 507 indicators; usage frequency 
Further, $83 \%$ (449) of the indicators are used in one or two studies only. Hence, there are a large number of indicators that are not commonly used, notably because they are very specific to a given destination. In fact, indicators commonly used in more than four studies are quite rare. The results are shown in Figure 4. These trends clearly demonstrate the lack of consensus in TDI. This is especially striking because the 11 studies retained examined recognized tourism destinations that offer fairly standard tourism products.

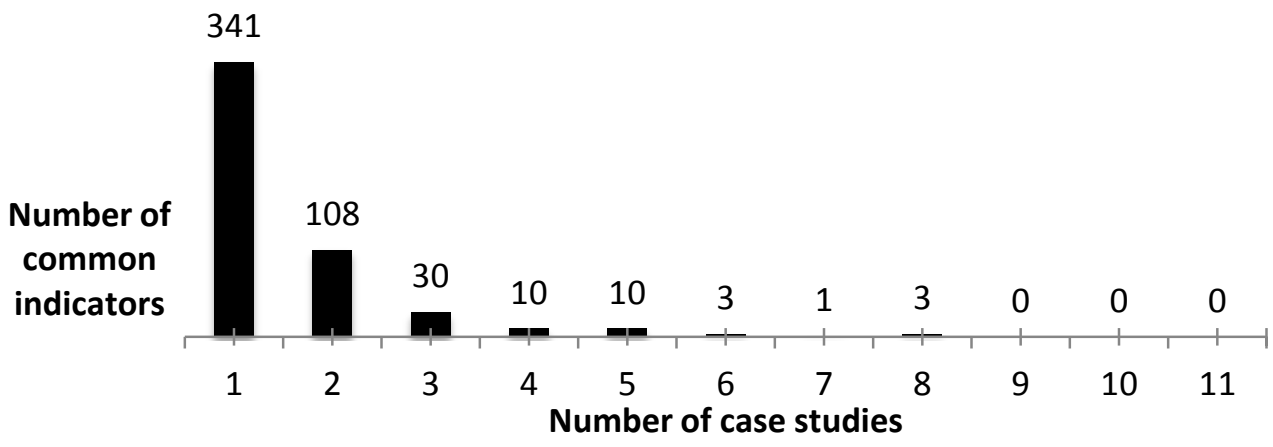

Figure 4 Frequency of use of the 507 indicators

Step 2: Frequency of use of the indicators

Of the 507 initial STI, 27 indicators have recognized and demonstrated pertinence and value. These 27 indicators are common to at least four studies, including 17 used in at least five of the 11 studies sampled.

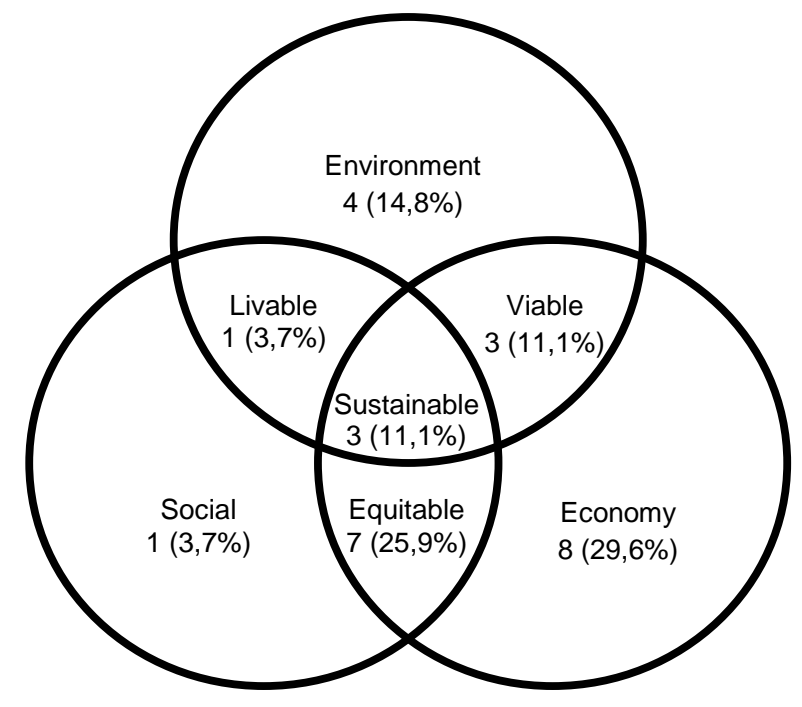

b) Indicators used in four case studies and more $($ total $=27)$

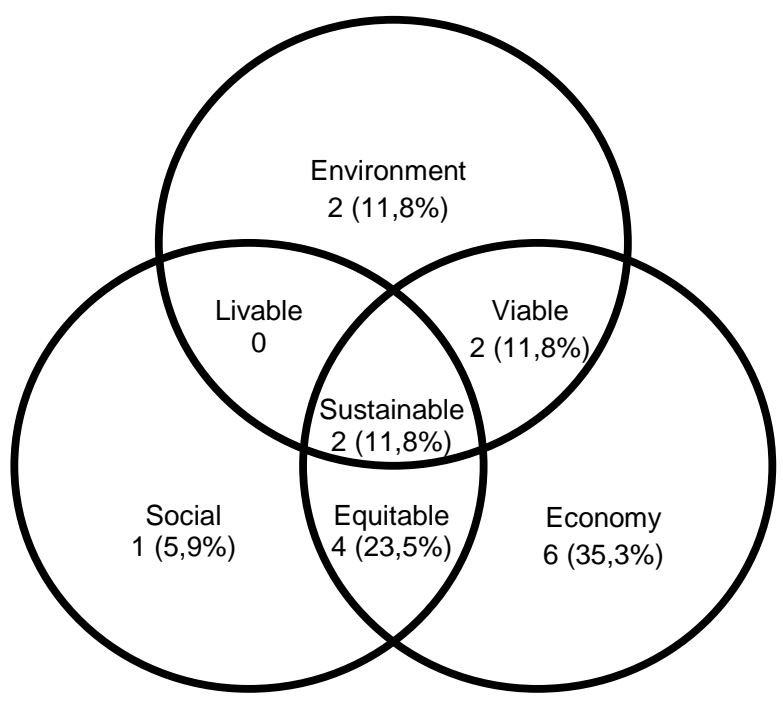

a) Indicators used in five case studies and more $($ total $=17)$

Figure 5 Classification of the most widely used indicators in the 11 studies 
At the thresholds of 27 and 17 indicators, the socioeconomic dimension is overrepresented, whereas the social and "livable" dimensions are underrepresented (Figures $5 \mathrm{a}$ and $5 \mathrm{~b}$ ). This confirms that the vast majority of studies emphasize economic and social dimensions in their evaluation of sustainable tourism.

By comparing the two Venn diagrams with the one of the initial 507 indicators, we clearly see that the indicators used in four case studies and more (Figure 5a) allow a percentage of coverage of the dimensions of sustainable development that most resembles that of the initial 507 indicators (Figure 4). The threshold of 27 indicators is therefore preferable to that of 17 indicators. The remaining selection criteria now apply to 27 indicators (Table 3).

Table 3 List of indicators cited four times or more in the 11 studies

\begin{tabular}{|c|c|c|}
\hline No & Indicator & of use \\
\hline 1 & Water consumption (tourism sector) & 8 \\
\hline 2 & Volume of tourists & 8 \\
\hline 3 & Occupancy rate of the main accommodations and restaurants & 8 \\
\hline 4 & Level of tourist satisfaction & 7 \\
\hline 5 & Level of satisfaction of the local population & 6 \\
\hline 6 & Number of tourists per $\mathrm{km}^{2}$ & 6 \\
\hline 7 & Existence of a tourism plan in the community & 6 \\
\hline 8 & Number of people encroaching on vulnerable sites & 5 \\
\hline 9 & Ratio between tourists and local population at cultural events & 5 \\
\hline 10 & $\%$ of new real estate developments intended for tourism & 5 \\
\hline 11 & $\%$ of jobs in the tourism sector held by local residents & 5 \\
\hline 12 & Average stay of tourists & 5 \\
\hline 13 & $\%$ of return visits of tourists & 5 \\
\hline 14 & Total number of arrivals of tourists (annual average and in high season) & 5 \\
\hline 15 & Volume of waste recycled & 5 \\
\hline 16 & $\%$ of revenues generated by tourism in the community & 5 \\
\hline 17 & Energy consumption (tourism sector) & 5 \\
\hline 18 & Canopy cover index & 4 \\
\hline 19 & Area of natural protected space & 4 \\
\hline 20 & Environmental vulnerability & 4 \\
\hline 21 & Local unemployment rate during low season & 4 \\
\hline 22 & Local population working in the tourism sector & 4 \\
\hline 23 & Ratio of jobs in tourism over total jobs & 4 \\
\hline 24 & $\%$ of businesses and establishments open year-round & 4 \\
\hline 25 & Spending by tourists & 4 \\
\hline 26 & Use of renewable energy sources & 4 \\
\hline 27 & Number of establishments that participate in the water conservation process & 4 \\
\hline
\end{tabular}


Step 3: Coverage of the main issues related to sustainable tourism

The 27 indicators do not systematically cover the dimensions of sustainable development and hence the issues that characterize sustainable development in sustainable tourism. To improve the coverage of these issues, we remove the least used indicators when the issue is overrepresented and add new indicators based on Choi and Sirakaya (2006) rating when the issue is underrepresented.

Given that the issues concerning water (quality and use), energy, tourist satisfaction, employment and volume are covered by at least two indicators, we remove the least cited or overrepresented indicators. One indicator is retained per issue. These indicators are:

- water consumption (tourism sector), for issues related to water;

- energy consumption (tourism sector) for issues related to energy;

- level of tourist satisfaction for issues related to satisfaction;

- $\quad \%$ of jobs in the tourism sector held by local residents for issues related to employment;

- volume of tourists and occupancy rate of establishments in the volume category;

- $\%$ of income generated by tourism for the economic vitality issue.

Six issues are not covered by the 27 indicators selected in the previous step. When possible, we supplement them with the indicators used more than once in the initial list of 507 indicators. If the usage frequency in the 11 studies is the same, we once again use the "Choi and Sirakaya rating" to determine the indicators to retain. The following indicators were added:

- $\quad$ air pollution (tourism sector)

- quality of bodies of water

- existence of a sustainable development plan

- level of use of existing transport modes to the destination

- maintenance level of heritage sites

- type of recognition of natural and cultural heritage

In the end, we obtain a reduced list of 20 indicators which covers the 20 main issues related to sustainable tourism.

\section{Step 4: Measurability of indicators over time}

Three of the 20 indicators retained in the previous steps were removed because they did not meet the condition of measurability over time. These indicators were: type of recognition of natural and cultural heritage, existence of a sustainable development plan 
and existence of a tourism plan in the community. These three indicators were replaced by: level of use of heritage and cultural sites, number (percentage) of businesses that acquired an eco-responsible label and the number of municipalities that have a sustainable tourism committee.

\section{Summary of the application of the general criteria}

A list of 20 indicators that satisfy the four preceding selection criteria (usage frequency, reproduction of the coverage of the components of sustainable development of the initial list, correspondence with the main sustainable issues in tourism and measurability of data over time) is obtained. It is presented in Table 4.

Table 4 The 20 STI satisfying the four general selection criteria

\begin{tabular}{|c|c|}
\hline Issues & Indicators \\
\hline Ecosystem & Area of natural protected space \\
\hline Water & Water consumption (tourism sector) \\
\hline Atmosphere & Air pollution (tourism sector) \\
\hline Energy & Energy consumption (tourism sector) \\
\hline Waste & Volume of waste recycled or treated/total volume generated \\
\hline Well-being & Level of satisfaction of the local population \\
\hline Resilience and risk & Environmental vulnerability \\
\hline Security and safety & Ratio of tourists to local population at cultural events \\
\hline Health & Quality of bodies of water (lakes, rivers, sea) \\
\hline Satisfaction & Level of tourist satisfaction \\
\hline Public participation & Level of public participation in election \\
\hline Culture & Level of maintenance of heritage sites \\
\hline Accessibility & $\begin{array}{l}\text { Frequency, capacity of services, or level of use by existing transport modes to } \\
\text { the destination }\end{array}$ \\
\hline Investments & $\%$ of new real estate developments intended for tourism \\
\hline Promotion of ecotourism & Number/percentage of businesses that acquired an eco-responsible label \\
\hline Economic vitality & $\%$ of income generated by tourism in the community \\
\hline Employment & $\%$ of new jobs in the tourism sector occupied by local residents \\
\hline Marketing & $\%$ of return visits \\
\hline Distinction & Number of visits to heritage and cultural sites \\
\hline Traffic & Volume of tourists \\
\hline
\end{tabular}

Further, we verify that the list of 20 indicators reproduces the coverage of the integrated components of the initial list fairly faithfully. This correspondence is summarized in Table 5. The results demonstrate that the 20 indicators considerably cover the dimensions of the initial sustainable development indicators. 
Table $5 \%$ distribution of the 20 STI $v s$ the $\%$ distribution of the 507 initial STI

Covering percentage Theoretical distribution Real distribution of 507 indicators $(\%)$

\begin{tabular}{rrrr}
\hline Livable & 4.9 & 0.98 & $\mathbf{1}$ \\
\hline Equitable & 24.2 & 4.84 & $\mathbf{4}$ \\
\hline Viable & 7.1 & 1.42 & $\mathbf{1}$ \\
\hline Sustainable & 24.6 & 4.92 & $\mathbf{3}$ \\
\hline
\end{tabular}

\section{Step 5: Availability and applicability of data}

In step 5, we start the process of applying specific criteria to the 20 remaining STI. The data corresponding to the 20 indicators obtained are not always available or applicable to all destinations. Many of these indicators are not calculated for the tourism area and even less for the local scale. For instance, water consumption is not always calculated on the municipal scale, as are energy consumption and air pollution. There are also indicators for which the calculation concerns areas that are not necessarily compatible with the administrative territorial division of the destination region. Examples include the area of protected space, which is reported according to more specific divisions. Although they may exist, some indicators could not be established because they are difficult to measure with the statistics currently available. In some particular cases, the data exist but have not been compiled for several years (i.e. level of satisfaction of the local population with tourism development). It would be advisable for the public authorities to develop statistics on these issues. In these cases, the list of the 20 key-indicators could help policy makers in the development of statistics for pertinent and recognized issues, for the evaluation of tourism in a sustainable development perspective. However, alternative indicators for which data is available can be considered when data is not available for the 20 STI. They must however cover the dimensions and issues of sustainable development related to tourism.

For example, we created a link between the 20 proposed indicators with the data and statistics available for the Gaspésie-Iles-de-la-Madeleine region of Quebec. 14 indicators are modified because of a lack of data. They are replaced by indicators for which data is available. However they must describe the same issues and cover the same aspects of sustainable development. The adjustments of indicators for this region are presented in table 6 . 
Table 6 Indicators available for Gaspésie-Îles-de-la-Madeleine

\begin{tabular}{|c|c|}
\hline Indicators satisfying the general criteria & Indicators available for the GÎM region \\
\hline Areas of natural protected spaces & Areas of natural protected spaces \\
\hline Water consumption (tourism sector) & Number of municipalities treating wasted water \\
\hline Air pollution (tourism sector) & Public transportation clientele \\
\hline Energy consumption (tourism sector) & Number of eco-labelled events \\
\hline Volume of waste recycled (tourism sector) & Volume of waste recycled \\
\hline Level of satisfaction of the local population & $\begin{array}{l}\text { GDP at domestic price of cultural industries, art, } \\
\text { entertainment and recreational industries and } \\
\text { accommodation and food services industries }\end{array}$ \\
\hline Environmental vulnerability & CRÉGÎM funds for environmental issues \\
\hline Ratio of tourists to local population at cultural events & Number of visits to museums and art galleries \\
\hline Quality of bodies of water (lakes, rivers, sea) & Number of accessible public beaches \\
\hline Level of tourist satisfaction & Level of tourist satisfaction \\
\hline Level of public participation in election & $\begin{array}{l}\text { Number of municipalities that have a sustainable } \\
\text { tourism committee }\end{array}$ \\
\hline Level of maintenance of heritage sites & Cultural spending of the public administration \\
\hline $\begin{array}{l}\text { Frequency, capacity of services or level of use of } \\
\text { existing transport modes to the destination }\end{array}$ & $\begin{array}{l}\text { Length of new roads added to the existing road } \\
\text { network }\end{array}$ \\
\hline $\begin{array}{l}\% \text { of new real estate developments intended for } \\
\text { tourism }\end{array}$ & $\begin{array}{l}\text { Capital spending by accommodation establishments } \\
\text { and restaurants }\end{array}$ \\
\hline $\begin{array}{l}\text { Number/percentage of businesses that acquired an } \\
\text { eco-responsible label }\end{array}$ & $\begin{array}{l}\text { Number of businesses that acquired the "Qualité } \\
\text { Tourisme Gaspésie" label }\end{array}$ \\
\hline$\%$ of income generated by tourism in the community & Tourists spendings \\
\hline $\begin{array}{l}\% \text { of new jobs in the tourism sector occupied by } \\
\text { local residents }\end{array}$ & Number of jobs in the tourism sector \\
\hline$\%$ of return visits & Average rate of occupancy of accommodations \\
\hline Number of visits to heritage and cultural sites & Number of visits to the national parks in the region \\
\hline Volume of tourists & Volume of tourists \\
\hline
\end{tabular}

Step 6: Coherence of indicators with the destination sustainable tourism policy

STI must also be harmonized with the overall sustainable tourism policy of this destination in order to be operational. For example, in the case of this region, five guiding principles were elaborated for this sustainable tourism policy. The indicators must be consistent with the guiding principles to be operational. In the case of GaspésieÎles-de-la-Madeleine, all principles are covered. If not, supplementary indicators would have been needed. Selecting these would have been done by the regional decisionmakers. Table 7 establishes the correspondence between the 20 indicators and the guiding principles for Gaspésie-Îles-de-la-Madeleine. 
Table 7 Correspondence between the indicators and the guiding principles of the policy framework for sustainable tourism of Gaspésie-Îles-de-la-Madeleine

Guiding principles $\mathbf{n}^{\circ}$ Indicators

\begin{tabular}{|c|c|c|}
\hline \multirow{2}{*}{$\begin{array}{r}\text { Safeguard and } \\
\text { development of the } \\
\text { Gaspesian culture }\end{array}$} & 1 & Number of visits to museums and art galleries \\
\hline & 2 & Cultural spending of the public administration \\
\hline \multirow{2}{*}{$\begin{array}{r}\text { Preservation and } \\
\text { development of the } \\
\text { Gaspesian landscape } \\
\text { heritage }\end{array}$} & 3 & Area of natural protected spaces \\
\hline & 4 & Number of visits to national parks located in the region \\
\hline \multirow{5}{*}{$\begin{array}{r}\text { Promotion of eco- } \\
\text { responsibility }\end{array}$} & 5 & Number of eco-labelled events \\
\hline & 6 & $\begin{array}{l}\text { Number of of businesses that acquired the "Qualité } \\
\text { Tourisme Gaspésie" label }\end{array}$ \\
\hline & 7 & Number of municipalities treating wasted water \\
\hline & 8 & Public transportation clientele \\
\hline & 9 & Volume of waste recycled \\
\hline \multirow[t]{2}{*}{$\begin{array}{r}\text { Participating governance } \\
\text { and endogenous } \\
\text { development } \\
\end{array}$} & 10 & $\begin{array}{l}\text { Number of municipalities with that have a sustainable } \\
\text { tourism committee }\end{array}$ \\
\hline & 11 & $\begin{array}{l}\text { GDP at domestic price of cultural industries, art, } \\
\text { entertainment and recreational industries and } \\
\text { accommodation and food services industries }\end{array}$ \\
\hline \multirow{9}{*}{$\begin{array}{r}\text { Sustainability of tourism } \\
\text { activities }\end{array}$} & 12 & Level of satisfaction of tourists \\
\hline & 13 & Volume of tourists \\
\hline & 14 & Number (percentage) of accessible public beaches \\
\hline & 15 & Spending of tourists \\
\hline & 16 & Length of new roads added to the existing road network \\
\hline & 17 & Number of jobs in the tourism sector \\
\hline & 18 & Average rate of occupancy of accommodations \\
\hline & 19 & CRÉGÎM funds for environmental issues \\
\hline & 20 & Capital spending by accommodations and restaurants \\
\hline
\end{tabular}


Step 7: Validation and adoption of indicators by consensus by regional decision-makers

The last of the seven criteria applied from the initial list of 507 indicators to the reduced list of 20 indicators is their adoption by consensus by regional decision-makers. In the case of Gaspésie-Îles-de-la-Madeleine, this one is made up of six administrative subregions. Each of them has its own particularities making it difficult or sometimes impossible to apply to all administrative sub-regions. It is therefore important that the indicators be validated and that consensus on these indicators be reached by the various decision-makers.

This step led to the revision of some of the indicators. They were replaced by equivalent indicators that truly apply to all RCMs of the region. These indicators should, however, be coherent and correspond to the guiding principles of the policy framework, and maintain the same coverage of the issues and dimensions of sustainable development of the previous STI.

In the case of the Gaspésie-Îles-de-la Madeleine region, this last step is being done. Further modifications to the 20 indicators is expected, mainly because the policy-makers do not have all the data pertaining to the chosen indicators (ex. average waste recovery rate, number of accessible public beaches) or because some of them cannot be applied.

\section{Discussion, conclusion and outlook}

First, the application of the general indicator selection criteria has guaranteed the neutrality of the process. We thus obtained a concise list of indicators whose pertinence has been demonstrated by experts and recognized in experience. In addition, these indicators systematically cover the main sustainable development issues in tourism, similar to the initial list of 507 indicators.

Second, we have examined the available data corresponding to these indicators for the Gaspésie-Îles-de-la-Madeleine region as an example to illustrate how flexible the selected STI are. When the data were unavailable, it is always possible to choose substitute indicators as long as the coverage of the sustainable development dimensions and issues in tourism are maintained. Because the indicators had to apply to regions that are frequently made up of smaller sub-regions, validation and adoption of the indicators by consensus by regional decision-makers is necessary, to ensure that the indicators are truly useful and inclusive.

Third, because the formulation of indicators is an evolving process, indicators may evolve from year to year. Practices in this area continue to be enriched by the destinations that have adopted tourism assessment tools; the contribution of indicators has become increasingly important in regional policies. Thus we recommend that the list of indicators 
be reviewed at least once every five years to allow public authorities and operators to review previous years and assess the needs and objectives for subsequent years.

Fourth, experience has demonstrated that the scientific production of sustainable development indicators - applied or not to a specific domain such as tourism - has a tendency to ignore or underestimate the policy dimension, and vice versa (Holman, 2009; Rametseiner et al., 2009; Terry, 2008; Holden, 2006). This could explain why indicators do not obtain social legitimacy from policy makers and society in general. On the other hand, an approach based on political or public consensus helps to take into consideration all stakeholders in order to define common goals. However, such an approach develops bias and introduces subjectivity which is not well received by scientists. Furthermore, the content and the priorities underlined in these indicators will depend on scientific affiliations of the participating experts.

Therefore, by proposing two types of criteria, we aim at obtaining STI which are expert recognized, legitimated by existing experiences and sufficiently flexible to be effective and useful for different destinations. We believe that these conditions will contribute to the recognition and, scientific and social legitimacy of STI by:

- Ensuring the credibility of selection using indicators that systematically cover the main issues of sustainable development in tourism;

- Ensuring the pertinence of indicators by establishing a concise list of indicators recommended by experts and recognized in existing experience;

- Ensuring the value of indicators by adapting them to the data available and the tourism policy of the destination.

Further, the aggregation of the 20 indicators into a sustainable development index was envisioned. Nonetheless, an OECD study published in May compared several countries using the better life index and notes methodological difficulties and problems of potential interpretation of an aggregation of indicators in an index (OECD, 2011). Compensation between indicators and the subjectivity introduced in the weighting are the main risks of an aggregation attempt. Bearing this in mind, we recommend that the 20 indicators retained be used without aggregation.

Lastly, although we recognize the subjective nature of our approach, we believe that the use of both general and specific STI selection criteria can allow the selection of recognized and complementary indicators while covering the various aspects of sustainable development as broadly as possible. Moreover, we reach the same conclusion as Niemeijer and De Groot (2008) in that selection of indicators is invariably subject to arbitrary decisions at one stage of the process or another. 
In addition, our analysis demonstrates that current practices related to STI cannot meet standard objectives. Thus, considering the contradiction between the need to obtain indicators that allow comparison between destinations and the desire to reflect individual concerns, it is probable that consensus on certain STI is a prerequisite to these objectives being met. Nonetheless, it should be acknowledged that this is a relatively new field that will surely benefit from ongoing and future initiatives.

\section{Bibliography}

Beauregard, R. A. (2003). "Democracy, Storytelling, and the Sustainable City". In Story and Sustainability, Eds.: Eckstein, B. and J. A., Throgmorton, p. 65-77. Cambridge: MIT Press.

Bell, S. and Morse, S. (2008). Sustainability Indicators: Measuring the Immeasurable? London: Earthscan, 2nd edition, 228 p.

Bouni, C. (1998). «L'enjeu des indicateurs de développement durable. Mobiliser des besoins pour concrétiser des principes ». Nature, Sciences et Société, 6 (3): 18-26.

Choi, H.C. and E. Sarakaya, (2006). "Sustainability indicators for managing community tourism". Tourism Management, 27 (6): 1274-1289.

Conférence regionale des élus de la Gaspésie-Îles-de-la-Madeleine [CRÉGÎM]. (2010). Pour un tourisme durable en Gaspésie. Policy framework of sustainable tourism of the Gaspésie. Gaspésie: CRÉGÎM, November 2010, 30 p.

Connelly, S. (2007). "Mapping Sustainable Development as a Contested Concept". Local Environment, 12 (3): 259-278.

Bouni, C. (1998). «L'enjeu des indicateurs de développement durable. Mobiliser des besoins pour concrétiser des principes ». Nature, Sciences et Société, 6 (3): 18-26.

European Environment Agency (2001). Environmental Benchmarking for Local Authorities : From concept to practice. Copenhagen: Environmental Issue Report, $\mathrm{n}^{\mathrm{o}}$ 20, $64 \mathrm{p}$.

Hall, C. M., \& Lew, A. A. (1998). "The geography of sustainable tourism development: Introduction”. In C. M. Hall, \& A. A. Lew (Eds.), Sustainable tourism: Geographical perspectives (pp. 1-24). New York, NY: Addison Wesley Longman Ltd.

Hunter, C. (1997). "Sustainable tourism as an adaptive paradigm". Annals of Tourism Research, 24(4): 850-867. 
Manning, E.W. and Dougherty, T.D. (1995). "Sustainable tourism: Preserving the golden Goose". Cornell Hotel and Restaurant Administration Quarterly (April), 29-42.

Mascarenhas, A., Coelho, P., Subtil, E., and Ramos T.B. (2010). "The Role of Common Local Indicators in Regional Sustainability Assessment”. Ecological Indicators, 10: 646-656.

Miller, G. (2001). "The development of indicators for sustainable tourism: Results of a Delphi survey of tourism researchers". Tourism Management, 22: 351-362.

Organisation for Economic CooperaIon and Development [OECD]. (2011). OECD Better Life Initiative : Executive Summary. OECD. Consulted on May $27^{\text {th }}, 2011$.

http://www.tourisme.gouv.qc.ca/publications/media/document/etudes-statistiques/tourreg-que-2007-2008.pdf

Rajaonson, J. et Tanguay, G., A. (2009). « Le développement durable au Québec : Classement des 25 plus grandes villes ». Canadian Journal of Urban Research, 18 (2): 40-77.

Sirakaya, E., Jamal, T., \& Choi, H. S. (2001). "Developing tourism indicators for destination sustainability". In D. B.Weaver (Ed.), The Encyclopedia of Ecotourism (pp. 411-432). New York, NY: CAB International.

Tanguay, G.A., Rajaonson, J., Lefebvre, J.F. and P. Lanoie (2009). "Measuring the Sustainability of Cities: An Analysis of the Use of Local Indicators". Ecological Indicators, 10: 407-418.

World Commission on Environment \& Development [WCED]. (1987). Our common future. Oxford, UK: Oxford University Press.

World Tourism Organization [WTO]. (2004). Indicators of Sustainable Development for Tourism Destinations: A guidebook. Madrid: UN-WTO, 514 p.

World Tourism Organization [WTO]. (2010). Faits saillants du tourisme. Édition 2010. Madrid: OMT, Section Faits and chiffres, Consulted on May 27, 2011. http://www.unwto.org/facts/eng/pdf/highlights/UNWTO Highlights10 fr HR.pdf

World Tourism Organization [WTO]. (2011). Tourisme international: les premiers résultats pour l'année 2011 confirment la consolidation de la croissance. Madrid: WTO, Press release May 11, 2011, Consulted on May 27, 2011. http://media.unwto.org/fr/press-release/2011-05-11/tourisme-international-lespremiers-resultats-pour-1-annee-2011-confirmen-0 